\title{
AN INFLUENCE OF SOCIAL DISTANCE ON TOURIST DECISION-MAKING PROCESS: A CASE OF TOURISTS VISITING THE MAASAI MARA NATIONAL GAME RESERVE Ashioya Belinda ${ }^{1 *}$, Imbaya Beatrice ${ }^{2}$, Timothy Sulo ${ }^{3}$ \\ ${ }^{1 *}$ Ph.D., Student School of Tourism, Hospitality and Events Management, Moi University, Kenya; ${ }^{2,3}$ Lecturer, School of Tourism, Hospitality and Events Management, Moi University, Kenya. Email: ${ }^{1 *}$ kisia@mmarau.ac.ke, ${ }^{2}$ bimbaya2000@yahoo.com, ${ }^{3}$ timothysulo@gmail.com Article History: Received on $3^{\text {rd }}$ February 2021, Revised on $28^{\text {th }}$ March 2021, Published on $7^{\text {th }}$ April 2021
}

\begin{abstract}
Purpose of the study: The study aims to assess the influence of social distance on the tourist decision-making process on tourists visiting the Maasai Mara National Game Reserve using the construal level theory.

Methodology: Exploratory research design was used using regression equation modeling. The Borgardus social distance scale was adapted to structure the questionnaire. A sample of 157 tourists was selected. The data were analyzed using descriptive and inferential statistics which were used to determine the relationship between the variables. The hypothesis was tested at a $5 \%$ level of confidence.
\end{abstract}

Main Findings: The study established that the majority of the respondents understood and indicated that social distancing influenced their choice of a destination. Social distance $(\mathrm{R}=0.580, \mathrm{p}=0.00<0.05)$ had a strong positive and significant influence on the contractual level of tourist choice of a destination. It was further established that construal level accounted for up to 33.6 percent of the variance in choice of destination $\left(\mathrm{R}^{2}=0.336\right)$.

Applications of this study: The study recommends that the conventional consumer behaviour model can be enhanced in decision making by incorporating the construal level of destination decision making for tourists. It will be beneficial to the tourists visiting Maasai Mara National Game Reserve, the marketers, hotels and destination owners, and the government at large.

Novelty/Originality of this study: Decision-making is central to the satisfaction of a customer that seeks value for his/her money. Though research in consumer decision-making has been conducted before its application in tourist's destination decision-making process remains new. This study sought to bring to light this link and fill this gap in the literature.

Keywords: Construal Level Theory, Consumer Decision Making Models, Social Distance, Tourist, Tourist Decision Making Process.

\section{INTRODUCTION}

Tourism has emerged as a global force: an essential economic sector with the ability to provide such benefits as $8.3 \%$ of global employment; $5 \%$ of the world's GDP; being a prominent export; contributing substantially to social progress, economic growth, and environmental sustainability. And in order to sustain its status, the United Nations World Tourism Organization (UNTWO) proposed that tourism be prioritized in national policy decisions and that competitive and responsible business models be developed to run it (UNTWO, 2019). Given the benefits of tourism, and if well developed, it can be an effective catalyst to the attainment of the Sustainable Development Goals (SDGs).

Kenya ranks high as a global tourist destination due to the diversity, particularly of fauna, historical and archeological sites, and the exemplary hospitality that is characteristic of the Kenya people (Kenya Tourism Strategy 2013-2018). Owing to the substantial contribution made by tourism to foreign exchange earnings, provision of employment, social progress, and infrastructural development, it is being relied upon, to a great extent, to realize the economic pillar of Kenya's Vision 2030. To make tourism more effective in its role, aggressive marketing in the source markets has been identified as a key activity to promoting Kenya as a destination (WTTC, 2018).

Tourism in Kenya registered a growth of 31.3\% between 2017 and 2018. International arrivals as of the end of 2017 were 1.475 million, earning Kenya 119 billion Kenya shillings. However, according to projections it had been expected that international arrivals would reach 3million and that Kenya would hit the 200 billion Kenya shillings mark with regard to earnings from tourism. This represents a shortfall of $51 \%$ in international arrivals and a $40 \%$ shortfall in earnings, not to mention the major slump that the industry suffered in 2015(Tourism Sector Performance Report, 2018).

The failure to attain desired targets can be attributed to the various challenges facing the industry generally, for instance, terrorism that resulted in travel advisories (Kimaiga et al., 2018). The Maasai Mara National Game Reserve (MMNGR) is a world-renowned tourist destination; a unique habitat due to the presence of a wide variety of wild animals. The spectacular 
annual wildlife migration involving more than one million wildebeests, a great herd of zebras, and Thomson's gazelles and other animals draws a large number of tourists to the MMNGR annually (Bhandari, 2017). Positioning the MMNGR as an important destination both globally (to tourists) and nationally (to the economy).

Maasai Mara ecosystem is faced with many challenges which include; climate change and land-use, ecosystem, political and economic, and human and cultural. Manifestations of these challenges influence the way tourists perceive MMNGR as a destination, which in turn affects the decision to visit or not to visit. But considering the degree to which Kenya relies on tourism, the momentum toward attaining the targets must be accelerated. Since marketing is the main tool that is used to communicate to source markets, models must be built; models that will improve communication effectiveness and be able to manipulate the very core of destination choice: and that is the tourists' decision-making process (Bhandari, 2017).

A number of studies Tan (2017), Chen and Rahman (2018) have been carried out to establish the relationship between psychological distance and the choice of destination as much as tourism has been recognized as a key contributor to economic growth and development over time focus of many researchers has been more on conservation (the destination) and less on the tourist (the customer). Aleshinloye et al. (2020) demonstrate that psychological distance influences the decisions concerning a vacation and the destination choice. However, these studies do not show how psychological distance interacts with the tourists' decision-making process in order to settle on a choice.

According to Balliet et al. (2017) Construal Level Theory (CLT) explains that psychologically an object can be removed from a person in the dimensions of time (temporal distance), space (spatial distance), social (social distance), and hypothetically (hypothetical Distance); and that in turn, these dimensions of distance enable the person to form abstract mental construal of distal objects and thus influence the person choices concerning the object in question (Schreurs et al., 2018). In other words, CLT offers an explanation as to how psychological distance is traversed from a person's standpoint to enable decisions and plans concerning distal objects. Since tourism involves choices about distal objects (destinations) this study intends to investigate the effect of the social dimension of psychological distance on the tourists' decision-making process (Prasad, 2019; Kumar et al., 2016).

\section{Objectives of the study}

The objective of this study was;

- To assess the effect of social distance on the tourists' decision-making process.

\section{LITERATURE REVIEW}

An understanding of consumer behaviour helps in understanding different market segments and developing strategies to effect a penetration into these markets. It also seeks to identify the gaps in shaping their desires and aspirations and solving many of the consumer's day-to-day problems in purchasing. Consumer decision-making is a process that begins with problem recognition and ends with post-purchase dissonance, and the process begins all over again (Kharouf et al., 2020).

CB remains one of the most researched areas in the marketing and tourism fields, with the terms 'travel behaviour' or 'tourist behaviour' typically used to describe this area of inquiry (Huete-Alcocer et al., 2019). According to Thyne et al. (2020), the existing body of research on travel behaviour can therefore best be seen as fragmented due to the fact that, among others, individual studies borrow consumer behaviour models for products and conventional services like banking, and apply them to tourism. Tourists highly engage in the choice process; making travel decisions risky, complex, and requiring large investments and efforts because tourism products and services are consumed away from home. Besides, tourists usually seek novelty that encourages them to consider options extensively (Celik, 2019).

Travel decisions involve the choice of destination, time period of visit, duration of stay, activities to undertake, purchases, accommodation, sites to visit (and itinerary), among others (Erul et al., 2020). The challenge is to make choices that will maximize the experience and yield the desired satisfaction. The consumer decision-making process goes through the stages of need development, information search, evaluation of alternatives, purchase decision, and the post-purchase dissonance; and the cycle begins all over again.

Decisions concerning tourism are much more complex because they entail purchasing a trip that will take place in the future at a geographically distant and (sometimes unfamiliar) destination; and will also involve encountering foreign communities with foreign cultures. That is why this study proposes the investigation of the effect of social distance on tourist decisionmaking. 


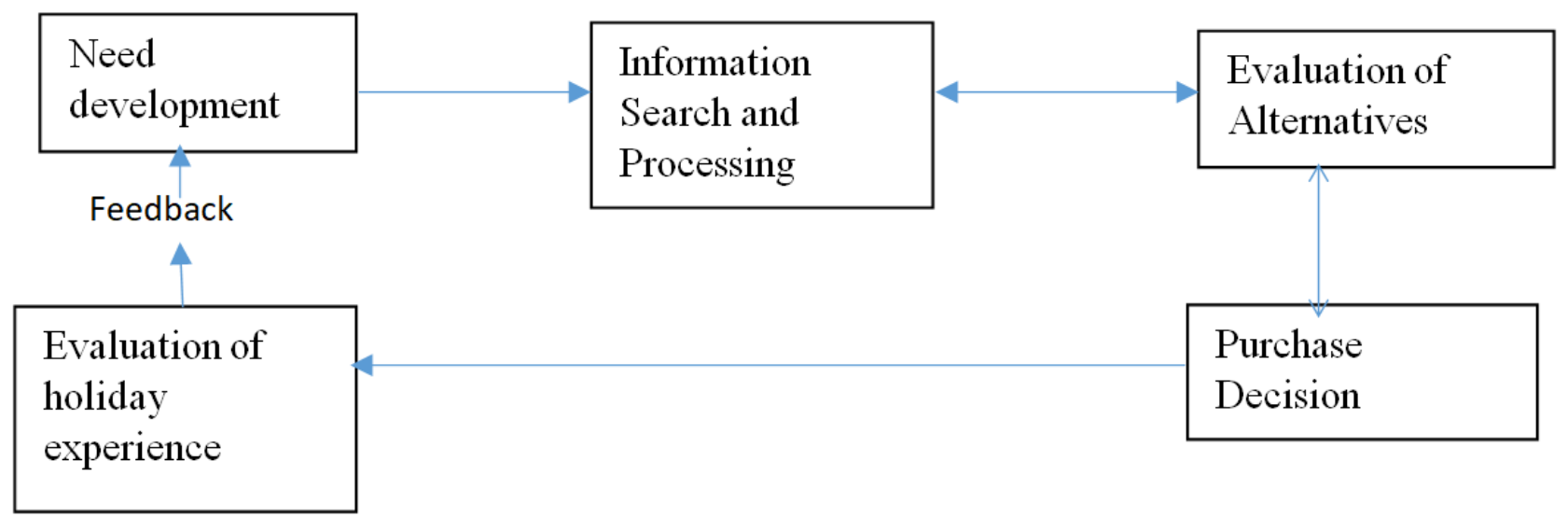

Figure 1: A model of the Conventional Decision-Making Process

Source: Author 2021

\section{Social Distance and Tourist Consumer Decision Making Process}

Construal level theory (CLT) is a social psychology theory that describes the relationship between psychological distance and the extent to which people's thinking is abstract or concrete, particularly when considering objects or events (Kalkstein et al. (2016). It assumes that people mentally construe objects that are psychologically near in terms of low-level, detailed, structured, and contextualized features, whereas at a distance they construe the same objects or events in terms of high-level, unstructured, abstract, and de-contextualized characteristics (Yankholmes \& Timothy, 2017). According to this theory, social distance manifests in such aspects as the distinction between self and others, similar and dissimilar others, and, in-group and out-group members (Woosnam et al., 2018). As tourism is a social activity tourism marketers need to recognize the effect that the social distance between the source market and the destination communities has on the tourist's decision-making process (Stephan et al., 2017)

Understanding the source markets, their expectations, and the choice process, are critical for the destination brand building and the planning and designing of appropriate marketing communication programs that will, in turn, allow tourists to make better destination choices that and optimize their experiences (Celik, 2019), (Celik and Dedeogly 2019).

Lee et al. (2018) noted that social distance is the measure of interpersonal space between individuals or social groups. According to Joo et al. (2018), Social distance is a feeling of closeness defined by how the people in different groups interact with each other and with other groups. If a social group feels secure and open with another group they would be exhibiting proximal social distance. This can also occur when they feel like the other social groups are similar to their group, therefore seeing the group as an extension of their social group. Among these cases, there is a feeling of insecurity and closed off from groups at far distances. Far distances are when people in a social group feel as if they cannot relate to the other group (Chen, \& Rahman, 2018). The implication is that cultural distance between home country and travel destination results in more reassurance and travel satisfaction.

A review of past studies by Celik (2019) reveals that very few studies have been carried out in the area of social distance and tourist decision making. Most of these previous studies sought to examine the effects of social and temporal distances on the responses to recommendations of others. Lee et al. (2018) evaluate international tourists' perception of cultural distance and recreation demand. Thyne et al. (2018) researched residents' perception of tourism focusing on the role of social distance. These studies show a growing interest in the social aspect of tourism, and specifically, what should be done with the host community in order to enhance the attractiveness of a destination. This study will focus on the effect of social distance on the tourists' decision-making process. The conceptual model is presented in figure 2.

\section{METHODOLOGY}

The quantitative design embedded in the positivism paradigm was adopted. The target population consisted of camp and hotel managers and tourists who visited Maasai Mara Game Reserve between the periods January to March 2020. A total of 4 camps and 8 hotels were sampled from the estimated 118 hotels and camps in the Maasai Mara Game Reserve. The study selected $10 \%$ of the hotels and camps using the Convenience sampling method as the target population constituting 12 managers and 115 tourists from different countries tourists visiting and staying at Maasai Mara Game Reserve (Kothari 2017). The data were collected through a self-administered questionnaire survey. The Bogardus Social Distance Scale was adopted and used to collect data from the respondents and also develop an interview schedule for the hotel owners. 


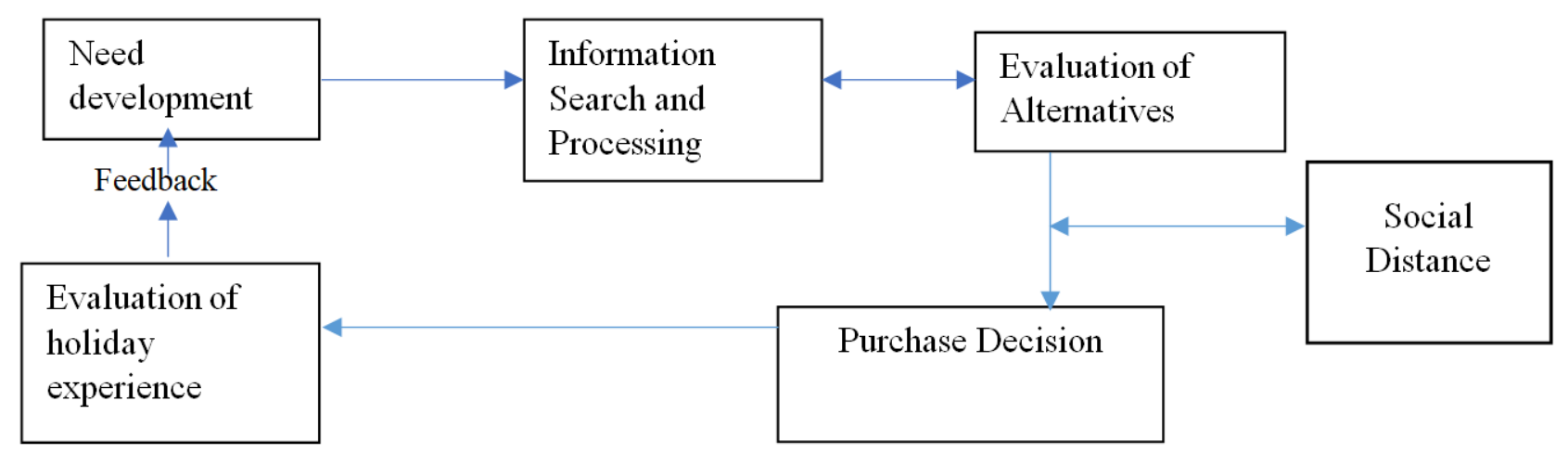

Figure 2: A Model of the Conventional Decision-Making Process Modified to Incorporate Social Distance

\section{Source: Author 2021}

The independent variable is perceived social distance and different items were used to measure this variable. The respondents were asked to provide their social-demographic characteristics and respond to specific statement items as provided in the Bogardus Social Distance Scale. The data collected was analyzed quantitatively were both descriptive statistics of frequency, percentages, a mean and standard deviation which helped to describe the characteristics of the data, and inferential statistics of correlation, ANOVA, and regression analysis which were used to assess the relationship between the variables. The hypothesis was tested at a 5\% level of confidence. The Statistical Package for Social Sciences version 23 was used to facilitate the data processing.

\section{FINDINGS AND DISCUSSION}

A total of 127 questionnaires were distributed were 12 of them were distributed to the managers of the various hotels and the rest 115 were distributed among the tourists from the hotels. The study recorded a response rate of $87.5 \%$ which was 101 of the total number of tourists considered for the study and this was appropriate for the analysis. The study used the same instrument as a way of ensuring that the findings can be checked for consistency. Though the managers were few but most of them were not readily available because of their schedule. It was therefore much easier to leave the questionnaires so that the respondents could respond to them in their own free time.

\section{DEMOGRAPHIC CHARACTERISTICS}

The study sought to assess the demographic characteristics of the respondents where the gender, age groups, education level, occupation, and the racial distribution of the tourists. The results showed that there were more male tourists $55 \%$ compared to only $45 \%$ of female among tourists that participated in the study. This was echoed by the 12 hotel manager's responses who indicated that for the period of the study there was relatively more male visiting the game reserve than female. The results also noted that more than 55\% of the respondents were in their middle age aged between 35 to 50 years while $30 \%$ were above 50 years. Only 15\% were below 35years which agreed with the statistics report of (UNWTO, 2019).

Table 1: Gender and Age

\begin{tabular}{ll}
\hline Gender & Percentage \\
\hline Male & $55 \%$ \\
\hline Female & $45 \%$ \\
\hline Age & \\
\hline Less than 35 years & $15 \%$ \\
\hline 35-45 years & $20 \%$ \\
\hline 45-55 years & $35 \%$ \\
\hline Above 55 years & $30 \%$ \\
\hline
\end{tabular}

Source: Author 2021

In terms of education level majority of the respondents over $76 \%$ indicated that they had received a college or graduate degree or above. This also supports the UNWTO (2019) report: In terms of occupation, half of the respondents are employed (50\%), 37\% were retirees and the rest $13 \%$ were students. This implied that the majority of the tourists at the Maasai Mara were on holiday and had fully sponsored their stay at the destination. In terms of income earned, the majority of the 
respondents $72 \%$ indicated that they earned between $\$ 4000$ and $\$ 20000$ on monthly basis, this indicates that the respondents had enough disposable income to take the adventure.

Table 2: Education level, occupation, and income level

\begin{tabular}{ll}
\hline \multicolumn{1}{c}{ Education } & Percentage \\
\hline Lower than College education & $0 \%$ \\
\hline College education & $24 \%$ \\
\hline Graduates degree and above & $52 \%$ \\
\hline Occupation level & \\
\hline Formal employment & $20 \%$ \\
\hline Businessperson & $30 \%$ \\
\hline Retired & $37 \%$ \\
\hline Students & $13 \%$ \\
\hline Income level & \\
\hline Less than $\$ 1000$ & $8 \%$ \\
\hline Between $\$ 1000-\$ 4000$ & $21 \%$ \\
\hline Between $\$ 4001-\$ 6000$ & $18 \%$ \\
\hline Between $\$ 6001-\$ 8000$ & $31 \%$ \\
\hline More than $\$ 8000$ & $23 \%$ \\
\hline
\end{tabular}

Source: Author 2021

The study also sought to assess the groupings in terms of country of origin where six classifications were considered for the study. The results were presented in table 4 . The results show that most of the respondents $29 \%$ had a European origin, 27\% from America, $20 \%$ from Nordic countries, $11 \%$ were from Asian countries, 9\% from China, and the rest were from African origin. This shows that most of the races were represented in the study and hence the objective of the study of assessing the influence of social distancing on the choice of a destination by tourists was likely to be met.

Table 3: Tourists Grouping by Origin

\begin{tabular}{ll}
\hline Grouping by origin & Percentage \\
\hline Europe & $29 \%$ \\
\hline America & $27 \%$ \\
\hline Nordic countries & $20 \%$ \\
\hline Asia & $11 \%$ \\
\hline China & $9 \%$ \\
\hline Africans & $5 \%$ \\
\hline
\end{tabular}

Source: Author 2021

The respondents were asked to indicate the previous frequency of their visits to different tourist destinations across the world in the past three years. The results were based on the racial groupings in Table 4 . The responses were assessed on a 10-scale grouped as $0,1,2,3,4,5,6,7,8,9 / 10$. The results show that most of the respondents $26 \%$ had made visits to different destinations only 5 times in the past three years, this was followed by $17 \%$ who had made at least 3 visits, $16 \%$ had visited at least 2 other different destinations, $14 \%$ had made at least 6 previous visits, and $9 \%$ had visited 7 and 8 previous destinations on earlier occasions. This implies that a good number of the visitors had an experience at other destinations and hence were in a position to provide the necessary information on driving factors in the choice of a destination. The study noted that most of the tourists who had visited the Maasai Mara Game with previous experience of other destinations were from Europe, America, and Nordic countries. This previous experience has an influence on decision-making in the choice of the destination in regard to social distance.

Table 4: Tourists grouping by origin

\begin{tabular}{|c|c|c|c|c|c|c|c|c|c|c|c|}
\hline Grouping by origin & & ce & tag & & & & & & & & \\
\hline & $\mathbf{0}$ & 1 & 2 & 3 & 4 & 5 & 6 & 7 & 8 & $9 / 10$ & \\
\hline Europe & 0 & 0 & 4 & 3 & 1 & 7 & 3 & 4 & 5 & 1 & $29 \%$ \\
\hline America & 0 & 1 & 5 & 6 & 0 & 6 & 3 & 2 & 3 & 1 & $27 \%$ \\
\hline Nordic countries & 0 & 2 & 3 & 4 & 0 & 7 & 3 & 1 & 0 & 0 & $20 \%$ \\
\hline Asia & 0 & 1 & 1 & 2 & 0 & 3 & 1 & 2 & 1 & 0 & $11 \%$ \\
\hline China & 0 & 2 & 2 & 2 & 0 & 2 & 1 & 0 & 0 & 0 & $9 \%$ \\
\hline
\end{tabular}




\begin{tabular}{llllllllllll}
\hline Africans & 0 & 0 & 1 & 0 & 0 & 1 & 3 & 0 & 0 & 0 & $5 \%$ \\
\hline Total & $\mathbf{0}$ & $\mathbf{6}$ & $\mathbf{1 6}$ & $\mathbf{1 7}$ & $\mathbf{0}$ & $\mathbf{2 7}$ & $\mathbf{1 4}$ & $\mathbf{9}$ & $\mathbf{9}$ & $\mathbf{2}$ & \\
\hline
\end{tabular}

Source: Author 2021

The study further sought to assess the level of international experience by the tourists. The results show that most of the respondents 34\% agreed that they were somewhat experienced, $33 \%$ were inexperienced with international destinations, and $17 \%$ said they were about the average experience with international travel. This implies most of the visitors had previous international experience.

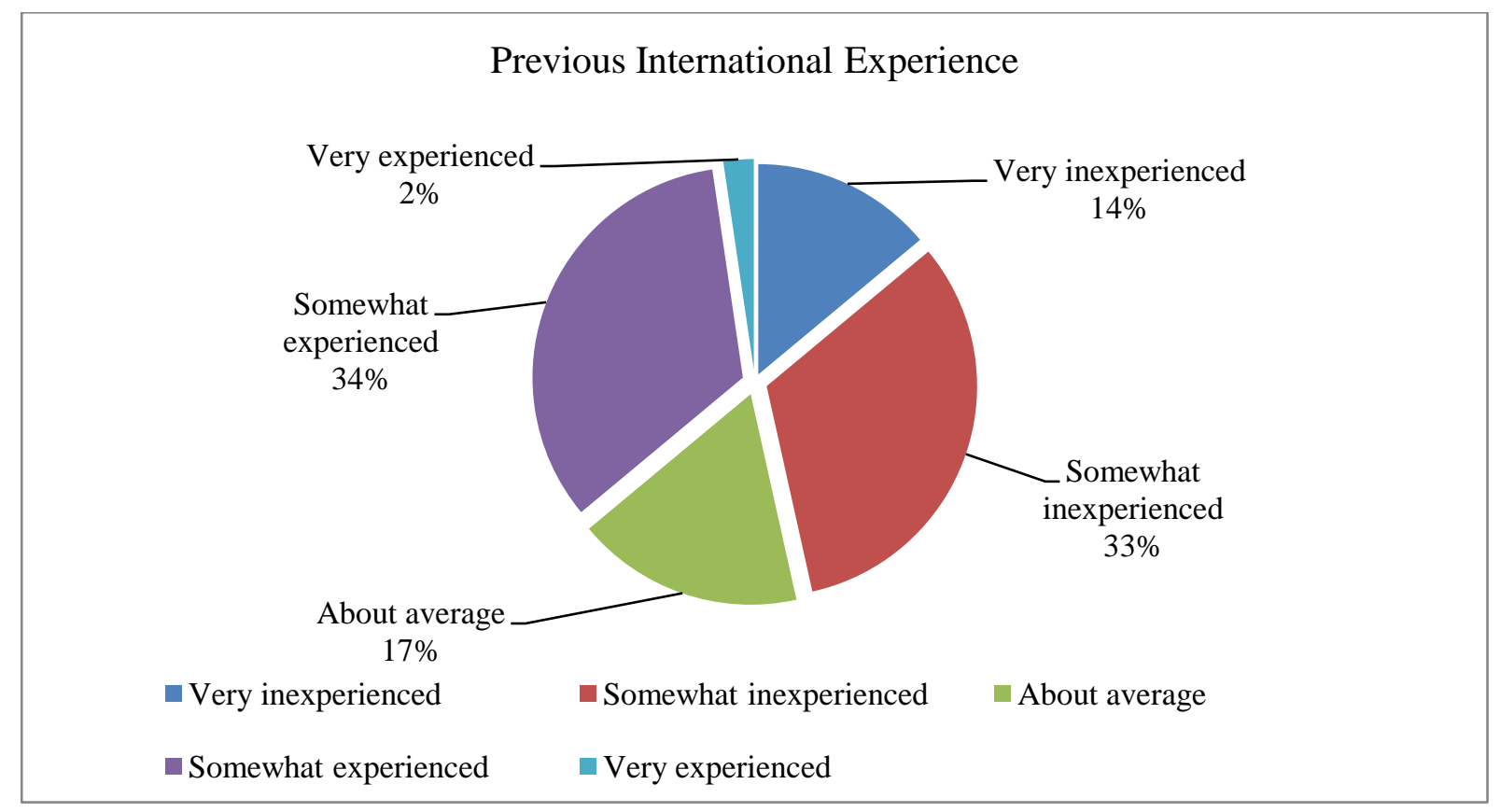

Figure 3: Previous international experience

Source: Author 2021

\section{Influence of Social Distance on the Choice of a Destination}

The Bogardus social distance scale was adopted and helped to assess the perception of the tourists in regard to social distance and the choice of their destination. On whether the respondents will accept a member of the group or the locals as a husband/ wife or engage in a sexual relationship with the members of the group, only $22 \%$ of the respondents indicated that they will marry a member from the group indicating that $78 \%$ of the respondents were not willing to marry. From this analysis, it is noted that tourists from America (47\%) and Europe (37\%) indicated that they would have a relationship which is intimate from any group without minding their cultural boundaries. This implies that the respondents were keen on the social distance existing between them and the community of the destination; hence majority was not ready to get into a lasting relationship with any member of the group or the host community.

The results also show that the visitors were keen on social distance as the majority indicated that they would prefer to stay with a person of their cultural background next door than have a total stranger. It was also noted that most of the visitors $55 \%$ indicated that they would be willing to hire an employee from the community of their destination despite their cultural differences while. On whether the respondents would accept to have a member of the group or from the host community as a business friend, $62 \%$ said they will be willing to have a business partner from among the group. The study further noted that most of the respondents $72 \%$ indicated they will be willing to share a tax with a member of the group or any member from the host community while the rest indicated that they would not share.

When asked whether the respondents would agree to give citizenship to any member of the group whether they adapt to their customs and morals or not, the results showed that most of the respondents $98 \%$ from the different countries indicated that they would give citizenship to any person in the group without consideration of whether they adapt to our customs and morals or not. Majority of the respondents $64 \%$ also indicated that they would not eliminate members of the group from their neighborhood. A similar proportion $64 \%$ indicated that they would not admit any of the group members as a visitor to their 
home country. This indicated that social distance is a very important factor in the consumer decision-making process when it comes to destination selection.

Table 5: Bogardus social distance scale

\begin{tabular}{lllllllll}
\hline Grouping & $\begin{array}{c}\text { I would } \\
\text { marry/engage in } \\
\text { a sexual } \\
\text { relationship in } \\
\text { the group }\end{array}$ & $\begin{array}{c}\text { I would } \\
\text { have a } \\
\text { close } \\
\text { friend } \\
\text { from } \\
\text { the } \\
\text { group }\end{array}$ & $\begin{array}{c}\text { I would be } \\
\text { at ease } \\
\text { living with } \\
\text { a member } \\
\text { of the } \\
\text { group next } \\
\text { door }\end{array}$ & $\begin{array}{c}\text { Would } \\
\text { work in } \\
\text { the same } \\
\text { office with } \\
\text { a group } \\
\text { member }\end{array}$ & $\begin{array}{c}\text { I would } \\
\text { have a } \\
\text { member of } \\
\text { this group } \\
\text { as an } \\
\text { employee }\end{array}$ & $\begin{array}{c}\text { I would } \\
\text { invite a } \\
\text { member of } \\
\text { this group } \\
\text { to my } \\
\text { home } \\
\text { country }\end{array}$ & $\begin{array}{c}\text { I would } \\
\text { share a } \\
\text { taxi with a } \\
\text { member } \\
\text { of this } \\
\text { group. }\end{array}$ & $\begin{array}{c}\text { Total } \\
\text { Europe }\end{array}$ \\
\hline America & $47 \%$ & $42 \%$ & $31 \%$ & $27 \%$ & $11 \%$ & $16 \%$ & $19 \%$ & $26 \%$ \\
\hline $\begin{array}{l}\text { Nordic } \\
\text { countries }\end{array}$ & $16 \%$ & $51 \%$ & $31 \%$ & $22 \%$ & $21 \%$ & $36 \%$ & $31 \%$ & $34 \%$ \\
\hline Asia & $10 \%$ & $15 \%$ & $9 \%$ & $12 \%$ & $9 \%$ & $12 \%$ & $11 \%$ & $12 \%$ \\
\hline China & 0 & $6 \%$ & $2 \%$ & $4 \%$ & $5 \%$ & $2 \%$ & $1 \%$ & $4 \%$ \\
\hline Total & $\mathbf{2 2 \%}$ & $6 \%$ & $2 \%$ & $7 \%$ & $5 \%$ & $1 \%$ & $11 \%$ & $5 \%$ \\
\hline
\end{tabular}

Source: Author 2021

The majority of the hotel managers confirmed that tourists from different countries exhibit differences in how they socialize with the rest of the tourists from other countries and the host country. It was revealed that tourists from the west were more social and could easily get along with their tourists from different countries with minimal restrictions. They were much at ease in the company of any other person including the locals as compared to tourists from the East. It was much easy for tourists from the west to make friends and give one an invitation as compared to those from the eastern side.

The study also sought to assess the influence of social distance on the choice of a destination in terms of perception, adoption, familiarity, and previous information about the destination. The perceptive attributes considered were; perceived social distance with the host community on cultural considerations, ease of adaptation to new environments, familiarity with the destination, and the amount of information about the destination that the tourists have were used. The mean value of each attribute for each country indicated that perceived cultural distance ranges from 2.24 to 3.9, with France having the highest mean in terms of cultural difference indicating; followed by China, South Korea, Singapore, the USA, and the UK this implies that there was a very large perceived cultural difference between these countries and the culture of the destination country. This influences construal factors influencing the application of consumer behavior theory.

Despite the cultural differences, the results show that the majority of the tourists found it easy to adapt to the environment of the destination countries, however, they observed social distance in terms of what they did and how they socialized: the perceived difficulty of adaptation ranges from 2.25 to 3.21. In terms of familiarity with other destination countries, the response ranged from 2.0 to 3.41. Tourists from Russia had the lowest familiarity with other countries. Based on information prior to the visit most of the respondents from the 15 countries noted that they had prior information with respondents from Vietnam having had the lowest prior knowledge while most respondents from Japan 3.52 had the highest prior knowledge about their destinations. Respondents had more tourism-related information about their host destination before they made the final decision to travel.

Table 6: Influence of Social Distance

\begin{tabular}{lllll}
\hline Country & Perceived CD & Adaptation & Familiarity & Information \\
\hline Australia & 3.2 & 2.47 & 2.14 & 3.16 \\
\hline Cambodia & 2.84 & 2.74 & 2.31 & 2.46 \\
\hline Canada & 3.1 & 2.85 & 2.48 & 2.65 \\
\hline France & 3.9 & 3.15 & 2.56 & 3.2 \\
\hline Italy & 3.74 & 3.21 & 2.54 & 2.58 \\
\hline Japan & 3.01 & 2.63 & 3.01 & 3.52 \\
\hline Malaysia & 2.46 & 2.25 & 2.37 & 3.06 \\
\hline Russia & 3.21 & 3.01 & 2 & 2.34 \\
\hline Singapore & 2.24 & 2.32 & 2.91 & 3.31 \\
\hline South Korea & 2.34 & 2.53 & 2.8 & 3.6 \\
\hline Switzerland & 3.46 & 3.21 & 3.42 & 2.8 \\
\hline
\end{tabular}




\begin{tabular}{lllll}
\hline Thailand & 2.78 & 2.53 & 2.76 & 3.04 \\
\hline UK & 3.57 & 3.12 & 2.83 & 3.02 \\
\hline USA & 3.71 & 3.12 & 2.87 & 3.14 \\
\hline Vietnam & 2.76 & 2.67 & 2.44 & 2.32 \\
\hline Average & $\mathbf{3 . 0 9}$ & $\mathbf{2 . 7 9}$ & $\mathbf{2 . 6 3}$ & $\mathbf{2 . 9 5}$ \\
\hline Percentage & $\mathbf{6 1 . 7 6 \%}$ & $\mathbf{5 5 . 7 5 \%}$ & $\mathbf{5 2 . 5 8 \%}$ & $\mathbf{5 8 . 9 3 \%}$ \\
\hline
\end{tabular}

Source: Author 2021

Key:Perceived CD: $1=$ very small, 5 = very large;Adaptation: 1 = very easy, $5=$ very difficult;

Familiarity: 1 = very unfamiliar, 5 = very familiar, Information: $1=$ very little, $5=$ very much.

\section{Correlation and Regression Analysis}

The study sought to establish the influence of integrating social distance as a construal factor in the consumer behaviour model was significantly correlated at a p-value of 0.05 . The results show that social distance has a strong positive and significant influence on the contractual level of tourist choice of a destination $(\mathrm{R}=0.58, \mathrm{p}=0.000<0.05)$. It was further established that construal level accounted for up to 33.6 percent of the variance in choice of destination $\left(R^{2}=0.336, p\right.$ $=0.000<0.05)$.

Table 7: Regression Coefficient Summary

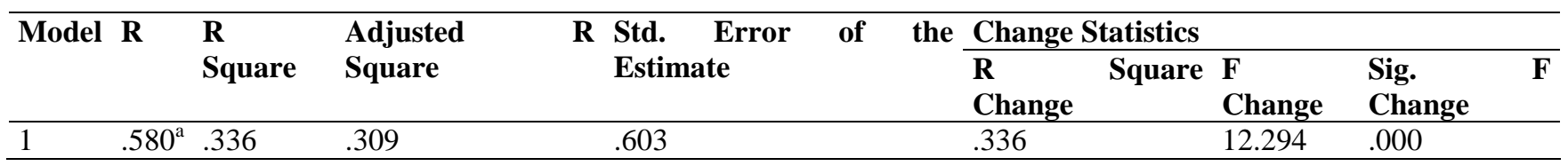

Source: Author 2021

The hypothesis that there is no significant influence of integrating the dimension of social distance on the consumer decision-making model for tourists visiting Maasai Mara Game Reserve was rejected. For this case, the alternative hypothesis that there is a significant influence of integrating the dimension of social distance on the consumer decisionmaking model for tourists visiting the Maasai Mara game reserve was accepted. This was based on the statistics that the F value was 12.294 and the $\mathrm{p}<0.05$.

Table 8: Analysis of Variance (ANOVA)

\begin{tabular}{|c|c|c|c|c|}
\hline Model & Sum of Squares & Mean Square & $\mathbf{F}$ & Sig. \\
\hline Regression & 17.856 & 4.464 & 12.294 & $.000^{\mathrm{b}}$ \\
\hline Residual & 35.222 & .363 & & \\
\hline Total & 53.078 & & & \\
\hline
\end{tabular}

Source: Author 2021

The regression coefficient model shows that integration of Social distance in the consumer decision-making model contributes to $53.2 \%$ change in the tourist decision-making model regarding the choice of the destination. This contribution is statistically significant given that $(\beta=0.532, \mathrm{t}=6.344>+2, \mathrm{p}=000<0.05)$.

Table 9: Regression Coefficients

\begin{tabular}{llllll}
\hline Model & \multicolumn{2}{l}{ Unstandardized Coefficients } & Standardized Coefficients & t & \multirow{2}{*}{ Sig. } \\
\cline { 2 - 5 } & B & Std. Error & Beta & & \\
\hline (Constant) & .169 & .448 & & .378 & .707 \\
\hline Social Distance & .532 & .084 & .638 & 6.344 & .000 \\
\hline
\end{tabular}

Source: Author 2021

The study results showed that social distance was an important factor to consider by the majority of the tourists when deciding on destination choice. The results further indicated that tourists from UK and USA were considered to be more social (Joo et al., 2018). This implies that by integrating the construal level of destination choice into the consumer behavior theory helps one to understand how psychological factors such as social distance influences a consumer's choice of a destination. This implies that apart from perceived social distance familiarity and adaptability of the tourists in the selection of a destination, having prior knowledge about the destination also accounted to a greater extent on the choice of a destination. Perceived cultural distance had the highest influence on the selection of a tourism destination. The correlation 
analysis shows that there is a positive significant relationship between the variables. This implies that integrating social distance as a construal factor in the consumer decision-making model has a very significant influence on the tourist destination choice. This agrees with the findings by Liu et al. (2017).

The results of this study are in line with the findings of Yan et al. (2016) who noted that when there is the less social distance between the tourists and the host country, the tourists tend to purchase more. It was also noted that the construal factors tend to influence consumer decision making and hence social distance is noted to have a positive effect on the consumer decisionmaking process. This implies that social distance influences the consumer decision-making process. However, Liu et al. (2017) indicate that the relationship between social distance and purchase decision making is quite complex, and calls for further analysis in future research.

\section{CONCLUSION AND RECOMMENDATIONS}

The study sought to assess the influence of integrating the dimension of social distance on the tourist consumer decisionmaking model for tourists visiting Maasai Mara Game Reserve in Kenya. The study considered the social distance as an important factor in consumer behavior influencing the tourist's choice of a destination. Based on the results the study concludes that integrating the social distance dimension in the consumer decision-making model influences tourist destination choice. This is because there is a positive correlation between the two constructs.

The study, therefore, recommends that hotel managers must focus more on understanding the influence of social distance on the choice of a destination by a tourist. These findings are very important in assisting the managers to design appropriate marketing strategies to use to attract more tourists to their destination.

\section{LIMITATIONS AND STUDY FORWARD}

This study was limited by time and the scope of the study which makes it difficult to generalize them to the entire population. The study used only a questionnaire to collect the data and this limited the amount of data that was collected hence the results can only be applicable to the current study area.

Therefore, there is a need to conduct research using more than one instrument to enhance triangulation and ensure the inclusion of more views and opinions that will ensure generalizations of the results.

\section{ACKNOWLEDGEMENT}

This paper would not have been a success without the efforts of many people who tirelessly contributed to it. Special thanks go to my supervisors Professor Sulo, Dr. Imbaya, and Mr. Indanya; for their support at the various levels of developing the study.

\section{AUTHORS CONTRIBUTION}

Ashioya conceptualized the study and through the guidance of Imbaya and Sulo. The study was conducted at Maasai Mara game reserve where data was collected and analyzed by Ashioya. Imbaya and Sulo did the editing of the final paper in preparation for the publication.

\section{REFERENCES}

1. Aleshinloye, K. D., Fu, X., Ribeiro, M. A., Woosnam, K. M., \& Tasci, A. D. (2020). The influence of place attachment on social distance: Examining mediating effects of emotional solidarity and the moderating role of interaction. Journal of Travel Research, 59(5), 828-849. https://doi.org/10.1177/0047287519863883

2. Balliet, D., Tybur, J. M., \& Van Lange, P. A. (2017). Functional interdependence theory: An evolutionary account of social situations. Personality and Social Psychology Review, 21(4), 361-388. https://doi.org/10.1177/1088868316657965

3. Benschop, N., Nuijten, A.L.P., Keil, M. et al. (2020). Construal level theory and escalation of commitment. Theory Decis. https://doi.org/10.1007/s11238-020-09794-w

4. Bhandari, R. (2017). Debts and Uncertainty: Circulation of Advance Money among Tourism Entrepreneurs in Agra, India, Research in Economic Anthropology, in: W., Donald C. (ed.), Anthropological Considerations of Production, Exchange, Vending and Tourism, 37, 233-256, Emerald Publishing Ltd. https://doi.org/10.1108/S0190128120170000037011

5. Çelik, S. (2019). Does tourism reduce social distance? A study on domestic tourists in Turkey. Anatolia, 30(1), 115126. https://doi.org/10.1080/13032917.2018.1517267

6. Çelik, S. and Dedeoğlu, B.B. (2019), "Psychological factors affecting the behavioral intention of the tourist visiting Southeastern Anatolia", Journal of Hospitality and Tourism Insights, 2(4), 425-450. https://doi.org/10.1108/JHTI01-2019-0005 
7. Chen, H., \& Rahman, I. (2018). Cultural tourism: An analysis of engagement, cultural contact, memorable tourism experience and destination loyalty. Tourism Management Perspectives, 26, 153-163. https://doi.org/10.1016/j.tmp.2017.10.006

8. Erul, E., Woosnam, K. M., Ribeiro, M. A., \& Salazar, J. (2020). Complementing theories to explain emotional solidarity. Journal of Sustainable Tourism, 1-16. https://doi.org/10.1080/09669582.2020.1800718

9. Huete-Alcocer, N., López-Ruiz, V. R., \& Grigorescu, A. (2019). Measurement of satisfaction in sustainable tourism: A cultural heritage site in Spain. Sustainability, 11(23), 6774. https://doi.org/10.3390/su11236774

10. Joo, D., Tasci, A. D., Woosnam, K. M., Maruyama, N. U., Hollas, C. R., \& Aleshinloye, K. D. (2018). Residents' attitude towards domestic tourists explained by contact, emotional solidarity and social distance. Tourism Management, 64, 245-257. https://doi.org/10.1016/j.tourman.2017.08.012

11. Kalkstein, D. A., Kleiman, T., Wakslak, C. J., Liberman, N., \& Trope, Y. (2016). Social learning across psychological distance. Journal of Personality and Social Psychology, 110(1), 1-19. https://doi.org/10.1037/pspa0000042

12. Kharouf, H., Biscaia, R., Garcia-Perez, A., \& Hickman, E. (2020). Understanding online event experience: The importance of communication, engagement and interaction. Journal of Business Research, 121, 735-746. https://doi.org/10.1016/j.jbusres.2019.12.037

13. Kumar, R. R., Stauvermann, P. J., Patel, A., Kumar, N., \& Prasad, S. (2016). Exploring the nexus between tourism and output in Cook Islands: an ARDL bounds approach. Social Indicators Research, 128(3), 1085-1101. https://doi.org/10.1007/s11205-015-1070-y

14. Lee, V. H., Hew, J. J., Leong, L. Y., Tan, G. W. H., \& Ooi, K. B. (2018). Mobile social tourism shopping: A dual-stage analysis of a multi-mediation model. Tourism Management, 66, 121- 139. https://doi.org/10.1016/j.tourman.2017.10.005

15. Liu, Q., Zhang, X., Huang, S., Zhang, L., \& Zhao, Y. (2020). Exploring consumers' buying behavior in a large online promotion activity: The role of psychological distance and involvement. Journal of theoretical and applied electronic commerce research, 15(1), 0-0. https://doi.org/10.4067/S0718-18762020000100106

16. Liu, Y., Sun, Q., Zhang, H., \& Lu, J. (2017). Increased social distance makes people more risk-neutral. The Journal of social psychology, 157(4), 502-512. https://doi.org/10.1080/00224545.2016.1242471

17. Nuraeni, S., Arru, A. P., \& Novani, S. (2015). Understanding consumer decision-making in tourism sector: conjoint analysis. Procedia-Social and behavioral sciences, 169, 312-317. https://doi.org/10.1016/j.sbspro.2015.01.315

18. Prasad, S., Nair, K., \& Purohit, H. (2019). Tourist Satisfaction: An Analysis of Push and Pull Factors-A Case of Qatar Tourism. Journal of Management (JOM), 6(2), 187-199. https://doi.org/10.34218/JOM.6.2.2019.022

19. Stephan, E., Shidlovski, D., \& Heller, D. (2017). Distant determination and near determinism: The role of temporal distance in prospective attributions to will. Journal of Experimental Social Psychology, 68, 113-121. https://doi.org/10.1016/j.jesp.2016.06.006

20. Tan, W. K. (2017). Repeat visitation: A study from the perspective of leisure constraint, tourist experience, destination images, and experiential familiarity. Journal of Destination Marketing \& Management, 6(3), 233-242. https://doi.org/10.1016/j.jdmm.2016.04.003

21. Thyne, M., Watkins, L., \& Yoshida, M. (2018). Resident perceptions of tourism: The role of social distance. International Journal of Tourism Research, 20(2), 256-266. https://doi.org/10.1002/jtr.2179

22. Thyne, M., Woosnam, K. M., Watkins, L., \& Ribeiro, M. A. (2020). Social Distance between Residents and Tourists Explained by Residents' Attitudes Concerning Tourism. Journal of Travel Research, 59 (5), 828-49. https://doi.org/10.1177/0047287520971052

23. UNWTO (2019). Understanding tourism: basic glossary.

24. Woosnam, K. M., Draper, J., Jiang, J. K., Aleshinloye, K. D., \& Erul, E. (2018). Applying self-perception theory to explain residents' attitudes about tourism development through travel histories. Tourism Management, 64, 357-368. https://doi.org/10.1016/j.tourman.2017.09.015

25. WTTC. (2018). Domestic Tourism: Importance and Economic Impact. London: WTTC.

26. Yan, B. J., Zhang, J., Zhang, H. L., Lu, S. J., \& Guo, Y. R. (2016). Investigating the motivation-experience relationship in a dark tourism space: A case study of the Beichuan earthquake relics, China. Tourism Management, 53, 108-121. https://doi.org/10.1016/j.tourman.2015.09.014

27. Kimaiga, R. K., Kihima, B. O., \& Nzioka, A. (2018). Homestay tourist accommodation as a tool for SocioEconomic Well-Being of rural communities in Kenya. Journal of Tourism and Hospitality Management, 6(4), 143151. https://doi.org/10.17265/2328-2169/2018.08.001

28. Kothari, C. (2017). Research methodology methods and techniques by CR Kothari. Published by New Age International (P) Ltd., Publishers, 91. 
29. Schreurs, B., Hamstra, M., Segers, M., \& Schmitte, K. (2018). Where to seat the applicant? How spatial distance influences the effect of self-promotion on interviewer evaluations. Journal of Applied Social Psychology, 48(8), 448-456. https://doi.org/10.1111/jasp.12524

30. Yankholmes, A., \& Timothy, D. J. (2017). Social distance between local residents and African-American expatriates in the context of Ghana's slavery-based heritage tourism. International Journal of Tourism Research, 19(5), 486-495. https://doi.org/10.1002/jtr.2121 